\title{
Evaluation of diagnosed cases of eye rhinosporidiosis in a public hospital of Maranhão, Northeast Brazil
}

Francílio Araújo Almeida', Antonio Augusto Lima Teixeira-Junior², Jaqueline Diniz Pinho', Elaine Fiod Costa ${ }^{3}$ and Gyl Eanes Barros Silva ${ }^{4,5^{*}}$

\begin{abstract}
Background: Oculosporidiosis (ocular rhinosporidiosis) accounts for $15 \%$ of cases of rhinosporidiosis, which is a chronic granulomatous disease and is endemic in India and Sri Lanka. In Brazil, the climatic and hydrographic similarities to these endemic areas and the presence of riverside populations contributes to an increase in the incidence of rhinosporidiosis particularly in the State of Maranhão. This study, therefore, aimed to identify the number of diagnosed cases of oculosporidiosis and describe its the clinical epidemiology, laboratory, histopathology, and therapeutic characteristics.
\end{abstract}

Methods: The study is descriptive, observational, and cross-sectional, and reports the prevalence and clinical epidemiological characteristics of oculosporidiosis in the State of Maranhão, Brazil. A retrospective analysis of the paper and electronic records for a period from 1999 to 2017 was conducted in the University Hospital of Federal University of Maranhão (HU-UFMA), located in the northeastern region of Brazil.

Results: Thirty patients were diagnosed with rhinosporidiosis, eight of them had oculosporidiosis and seven of these met the criteria to be included in the study. Of the cases (23.3\% of all 30), five were men (71.4\%) and two women $(28.5 \%)$, with an average age of $16.4 \pm 15.6$ years. In terms of race, four patients (57.1\%) declared themselves white and three (42.9\%) as brown. The north of the state, the mesoregion, had the most diagnosed cases accounting for $57.1 \%$ of the total. Left eye was the most affected site, reported in six patients (85.7\%), while the conjunctiva was affected in all patients. Rhinosporidiosis and papilloma were the predominant diagnostic hypotheses (28.5 and 28.5\%, respectively), followed by chronic scleritis, granuloma, and chalazion (14.25, 14.25, and $14.25 \%$, respectively). All these cases were treated with lesion excision, and only two patients (28.5\%) progressed with recurrence.

Conclusion: It was verified that there was a male predominance, with only one eye reported as an infected site, with no bilateral involvement. The younger age group (between 1 and 2 years of age) was more affected by oculosporidiosis, and histopathological examination was necessary for a conclusive diagnosis.

Keywords: Oculosporidiosis, Rhinosporidiosis, Maranhão

\footnotetext{
* Correspondence: gyleanes@fmrp.usp.br

${ }^{4}$ Department of Pathology, Ribeirão Preto Medical School, University of São

Paulo, Ribeirão Preto, São Paulo, Brazil

${ }^{5}$ Barão Itapary Street, 227, 65020 070, São Luís, Maranhão, Brazil

Full list of author information is available at the end of the article
}

(c) The Author(s). 2019 Open Access This article is distributed under the terms of the Creative Commons Attribution 4.0 International License (http://creativecommons.org/licenses/by/4.0/), which permits unrestricted use, distribution, and reproduction in any medium, provided you give appropriate credit to the original author(s) and the source, provide a link to the Creative Commons license, and indicate if changes were made. The Creative Commons Public Domain Dedication waiver (http://creativecommons.org/publicdomain/zero/1.0/) applies to the data made available in this article, unless otherwise stated. 


\section{Background}

Rhinosporidiosis is a chronic granulomatous disease caused by Rhinosporidium seeberi, categorized as microorganism protist of the class Mesomycetozoea, through ribosomal DNA analysis [1-3]. The most common sites of infection are the nose and nasopharynx (70\%), followed by the eyes (15\%). The rare sites of involvement are the: penis, lips, skin, and uvula [4-6].

The disease has the highest number of cases in India and Sri Lanka [5]. In Brazil, the great majority of the cases are noted in the State of Maranhão [7-10]. Rhinosporidiosis mainly affects males and has a predominance between the second and fourth decades of life $[6,11,12]$.

Transmission of the disease occurs through the traumatized epithelium (transepithelial infection), which comes in contact with contaminated water and / or soil $[3,13]$. Patients subsequently develop a mass of polypoid traits, which is pedunculated, and associated with bleeding, pruritus, and sneezing $[11,14]$.

In the ocular region, the conjunctiva and lacrimal sac are the most affected areas, representing between 50 to $77.6 \%$ and 24 to $33 \%$ of cases, respectively. In addition, the sclera and eyelid are also affected by oculosporidiosis [1, 10, 15-17]. In both tarsal and bulbar sides may be affected in the conjujctiva, with predominance in the tarsal region [18].

Clinically, oculosporidiosis appears as a friable polypoid mass, causing a foreign body sensation, with irritation and watering from the eye, and with no effects on visual acuity according to some isolated case reports $[3,16,19,20]$.

A rare complication of the lesion in the conjunctival region is the formation of staphyloma, which occurs due to scleral thinning and herniation of the intraocular content. This can lead to rupture and loss of the intraocular content, along with its infection due to scleral tissue dissolution, caused by the overlap of $R$. seeberi [21, 22].

The differential diagnosis includes mainly papilloma and pyogenic granuloma, which are treated with surgical excision of the lesion and cauterization of its base [13, $23,24]$. In association with surgery, dapsone is used to prevent the maturation of sporangia and promote fibrosis $[25,26]$. The definitive diagnosis is obtained by histopathological examination, with demonstration of a fibrous stroma with several thick-walled sporangia at different stages of maturation and containing numerous endospores [24, 27, 28].

Although Brazil contains areas with high incidence of the disease, few cases have been reported in the country, mainly in the ocular form. Therefore, it was proposed to retrospectively raise the cases of this form of presentation of the disease in a specialized reference center in the State of Maranhão and to describe the clinical, epidemiological, laboratory, histopathological and therapeutic conduct characteristics, as well as to serve as bibliographical reference for professionals who have little knowledge about oculosporidiosis and rhinosporidiosis in general.

\section{Methods}

The study is descriptive, observational, and retrospective study in nature. The study was developed at the Pathology Anatomy Unit of the University Hospital of the Federal University of Maranhão (HU-UFMA).

The oculosporidiosis cases were studied using the following data: epidemiological (such as age, sex, color, and place of residence), clinical aspects related to the lesion (such as location, time of evolution, and symptoms), and the histopathological examination, which included the complete diagnosis and treatment. The data were collected from information contained in the paper and electronic medical records. Patients with ocular lesions, that confirmed rhinosporidiosis on histopathological examination between 1999 and 2017, were enrolled in this study.

The exclusion criteria were unavailability of the medical records or paraffin block. The data were evaluated and transferred on to a Microsoft Excel 2010 spreadsheet, where results were arranged in a tabulated format.

\section{Results}

Thirty patients with a diagnosis of rhinosporidiosis (through histopathological examination) were enrolled in this study, eight of these presented ocular involvement by the disease. One of the patients was excluded because of incomplete medical data. Thus, seven patients with oculosporidiosis were evaluated in this study, corresponding to $23.3 \%$ of the total number of patients with rhinosporidiosis. Of these, five were men (71.4\%) and two women (28.5\%), predominantly young, aged between 5 and 51 years: three in the first decade of life (42.9\%), three in the second (42.9\%), and one was in sixth decade of life (14.25\%), with an average age of $16.4 \pm 15.6$ years. Regarding color or race, four declared themselves as white $(57.1 \%)$ and three as brown (42.9\%) (Table 1). As for the origin, the northern Maranhão, the mesoregion of the state, had a greater number of cases, four patients (57.1\%) (Fig. 1).

In six of the cases (85.7\%), lesions were identified in the left eye, while only one (14.25\%) had in the right eye. In all the cases, the conjunctiva was the primary lesion site, six were in the tarsal conjunctiva $(85.7 \%)$ and one in the bulbar conjunctiva (14.25\%). The disease progression described in the medical records (i.e. beginning of the injury until medical attention) was between 3 months and 3 years, with an average of $18.6 \pm 13.8$ months (not including episodes of recurrence).

The following symptoms were reported: episodes of bleeding, irritation, and decreased visual acuity (Table 2). 
Table 1 Clinical-epidemiological characteristics of patients with oculosporidiosis in HUUFMA, Maranhão (1999-2017)

\begin{tabular}{|c|c|c|}
\hline Variables & $\mathrm{N}$ & $\%$ \\
\hline \multicolumn{3}{|l|}{ Gender } \\
\hline Male & 5 & 71,4 \\
\hline Female & 2 & 28,5 \\
\hline \multicolumn{3}{|l|}{ Age group } \\
\hline $1-10$ & 3 & 42,9 \\
\hline $11-20$ & 3 & 42,9 \\
\hline $51-60$ & 1 & 14,25 \\
\hline \multicolumn{3}{|l|}{ Color } \\
\hline White & 4 & 57,1 \\
\hline Brown & 3 & 42,9 \\
\hline \multicolumn{3}{|l|}{ Location } \\
\hline São Luís & 1 & 14,25 \\
\hline Other cities & 6 & 85,7 \\
\hline \multicolumn{3}{|l|}{ Location of injury } \\
\hline Left eye & 6 & 85,7 \\
\hline Right eye & 1 & 14,25 \\
\hline \multicolumn{3}{|l|}{ Diagnostic hypothesis } \\
\hline Oculosporidiosis & 2 & 28,5 \\
\hline Papilloma & 2 & 28,5 \\
\hline Chronic Scleritis & 1 & 14,25 \\
\hline Calazio & 1 & 14,25 \\
\hline Granuloma & 1 & 14,25 \\
\hline
\end{tabular}

The complication of staphyloma formation was observed in only one patient (14.25\%) (Fig. 2). The diagnostic hypothesis was follows: rhinosporidiosis suspected in two patients $(28.5 \%)$, papilloma in the other two (28.5\%), while chronic scleritis, chalazion, and granuloma in one patient each (14.25\%). There was no case of dacryocystitis and sinusitis reported. In the medical records, three patients $(42.9 \%)$ had laboratory tests reported, with two presenting alterations in their eosinophil values: first one with $18 \%$ and $1702 \mathrm{~mm}^{3}$ (maximum reference values of $5 \%$ and $500 \mathrm{~mm}^{3}$ ), and the second with $5.9 \%$ and 655.49 $\mathrm{mm}^{3}$ (maximum reference values of $5 \%$ and $500 \mathrm{~mm}^{3}$ ).

All patients were treated by surgical excision of the lesion, without the use of any complementary medication. Two patients $(28.5 \%)$ had regular clinical follow-up: one underwent surgery 1 year and 3 month after the first one for staphyloma repair, while the other patient presented with two recurrences within the 1 year and 5 month period, with excisions being performed.

The macroscopic aspects of all biopsies in the histopathological reports were described mainly as rough, brown, friable, and elastic consistency. The microscopic analysis of three patients reported, respectively: stratified squamous epithelial lining exhibiting mononuclear inflammatory infiltrate, with structures suggestive of $R$. seeberi sporangia (Fig. 3); pseudoepitheliomatous hyperplasia; and reactional hyperplasia of the squamous and glandular epithelium.

\section{Discussion}

This study, involving a small sample, brings conformities with scientific articles, in both epidemiological and clinical factors. The ocular region represents on average $15 \%$ of cases of rhinosporidiosis, this study, however, presented a higher percentage than the literature data $[22,29]$. The presumed mode of transmission of the disease from the natural aquatic habitat of $R$. seeberi, is through traumatized epithelium. The risk factors are related to the tropical climate zones, activities involving contact with soil or mud in a rural setting and bathing in still water $[15,17]$. The higher frequency of cases among males could be related to rural activities, while among younger age groups could be ascribed to the habit of bathing in pond water $[6,28]$.

The typical oculosporidiosis lesion is a freely mobile, granular pink or red, sessile or pedunculated lesion $[17,18]$. There was only one-sided involvement. The conjunctiva is the site with the highest infection rate, with granuloma formation due to foreign matter deposited in the conjunctiva. In all of our cases, patients presented conjunctival lesions, mainly in the tarsal conjunctiva (see Fig. 4). The time of lesion evolution varies between 3 months and 1 year $[16,19$, $22,24,30$ ] with an average of $9 \pm 5.09$ months, a time relatively close to that found in the sample, which had an average evolution of symptoms around 18.6 months.

Visual impairment or loss in oculosporidiosis is a rarely seen as a clinical complaint or measured during the ophthalmologic examination. From the literature, 1 case of 5 that evaluates visual acuity, presented visual loss measured at the ophthalmological examination [1, $3,16,20,21,29]$. While in our study, two of the patients reported visual complaint associated with ocular discomfort. The frequency of staphyloma, one of the complications of oculosporidiosis, is minimal, even in the endemic regions. It is also a recent finding, with the first cases recorded over 10 years, and according to analysis, there is an extension of the lesion to the retina [20-22]. One of the patients (14.25\%) in our study developed this complication, requiring two surgeries for its correction.

The rates of suspecting rhinosporidiosis is low, considering it is a rare disease [2]. Suspicion is higher in countries where it becomes endemic, and thus physicians are more familiar with the disease [12, 15]. Regarding oculosporidiosis, this was considered a diagnostic hypothesis in $28.5 \%$ of our cases, a percentage similar to the papilloma, one of the main differential diagnosis.

Laboratory findings were not cited in most papers. In a case report of disseminated rhinosporidiosis, the patient 


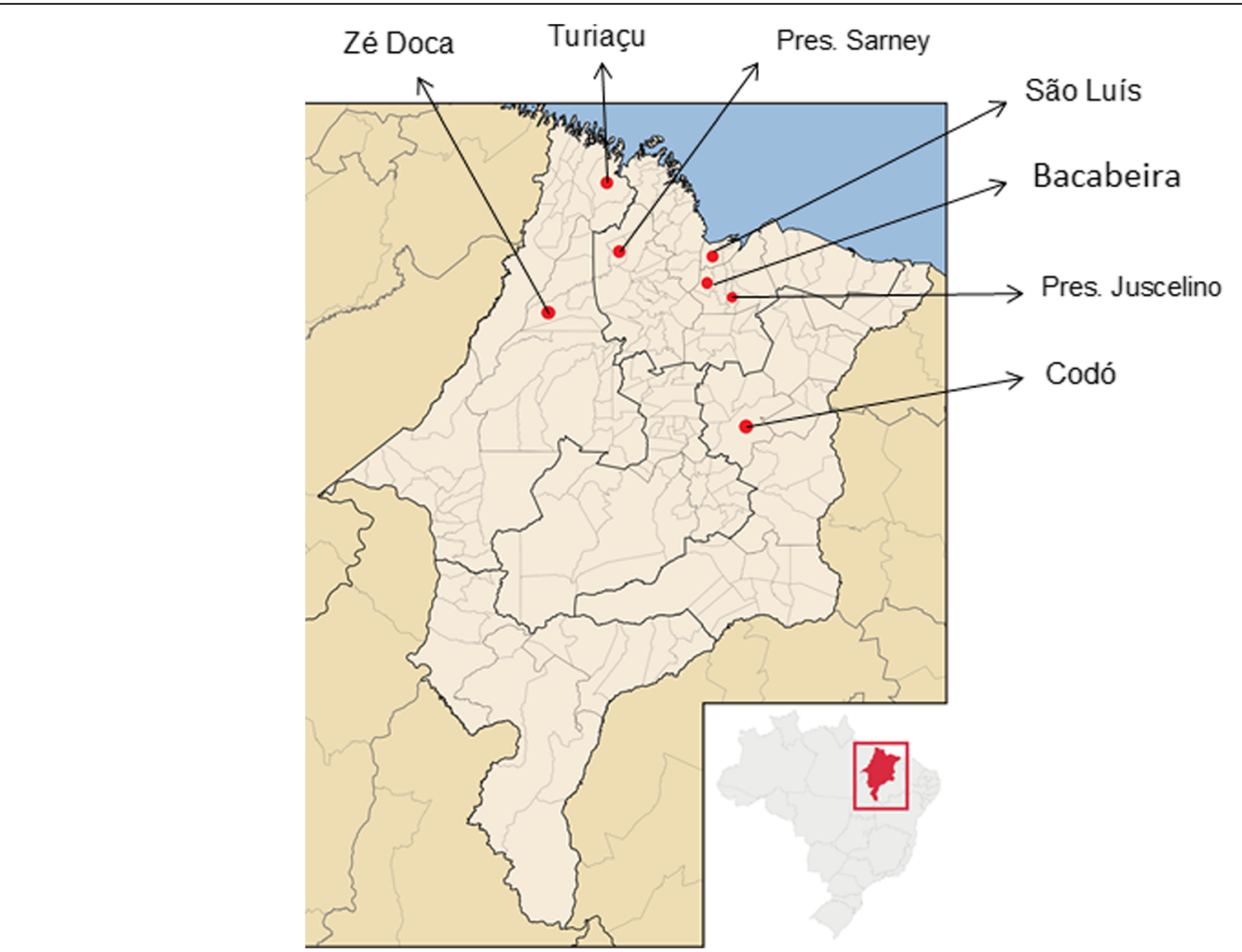

Fig. 1 Geographic distribution of cases of oculosporidiosis between 1999 and 2017 in the State of Maranhão, Brazil (adapted from https://pt.wikipedia.org/wiki/Maranh\%C3\%A3o\#/media/File:Maranhao_MesoMicroMunicip.svg)

presented $40 \%$ eosinophilia [4]. In another study, 10 patients out of a total of 63 had eosinophilia; however, values were not cited in the paper [31]. Two out of three patients with laboratory tests in our study revealed eosinophilia, and one of these showed a high increase with the maximum reference value. In such cases, the diseases with the same laboratory findings, such as parasitosis, however, cannot be ruled out [4].

Surgical removal of the lesion is the treatment of choice for oculosporidiosis, and it is recommended to use the adjunctive dapsone therapy to prevent sporangia maturation and promote stroma fibrosis $[6,13,17]$. Ocular recurrences are typically rare, with $1 \%$ rate for the conjunctiva, and between 2 and $40 \%$ for the lacrimal sac [26, 27, 32]. The causes: are incomplete excision of the lesion and spreading of endospores to the adjacent sites during a surgical procedure $[14,33]$. The ineffective cauterization of the base of

Table 2 Clinical signs and symptoms of patients with oculosporidiosis in HUUFMA, Maranhão (1999-2017)

\begin{tabular}{lll}
\hline Variables & $\mathrm{N}$ & $\%$ \\
\hline Bleeding & 02 & 28,6 \\
Rashes & 02 & 28,6 \\
Loss of sight & 02 & 28,6 \\
Not available & 01 & 14,2 \\
\hline
\end{tabular}

the lesion and failure to use dapsone in the postoperative period may make the lesion more susceptible to relapses. Despite being a benign condition, oculosporidiosis should be treated, as some cases can be lingering, locally invasive and devastating $[16,26,32]$.

In the histopathological examination, $R$. seeberi is observed at all stages of development, and it is not possible to correlate some specific form of evolutionary stage with clinical presentation [34]. The literature describes some

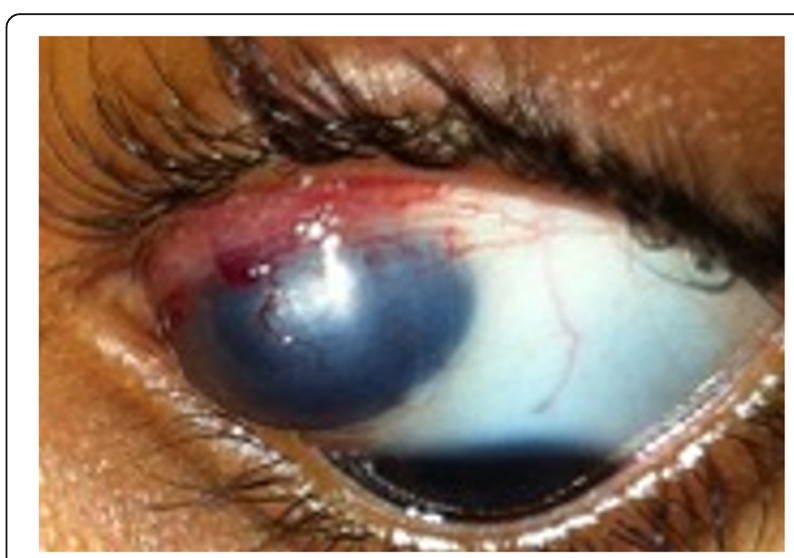

Fig. 2 Conjunctival oculosporidiosis with staphoma in the left eye (image courtesy of Prof. Elaine de Paula Fiod Costa, UFMA) 


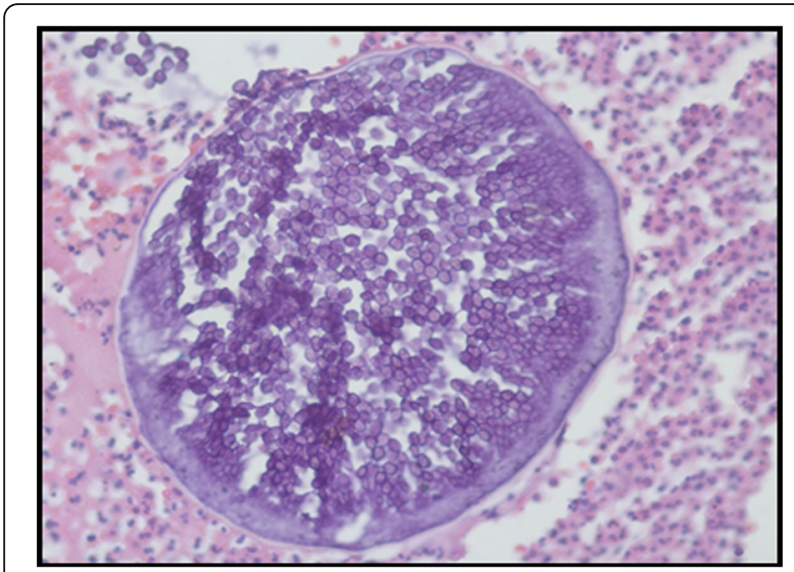

Fig. 3 Sporangium containing several endospores surrounded by inflammatory infiltrate

histological findings associated with infection, citing squamous metaplasia and epithelial hyperplasia [9, 19, 25].

\section{Conclusion}

In our study, we described a large oculosporidiosis rate, one of the higher available in the literature (23.3\%). Even

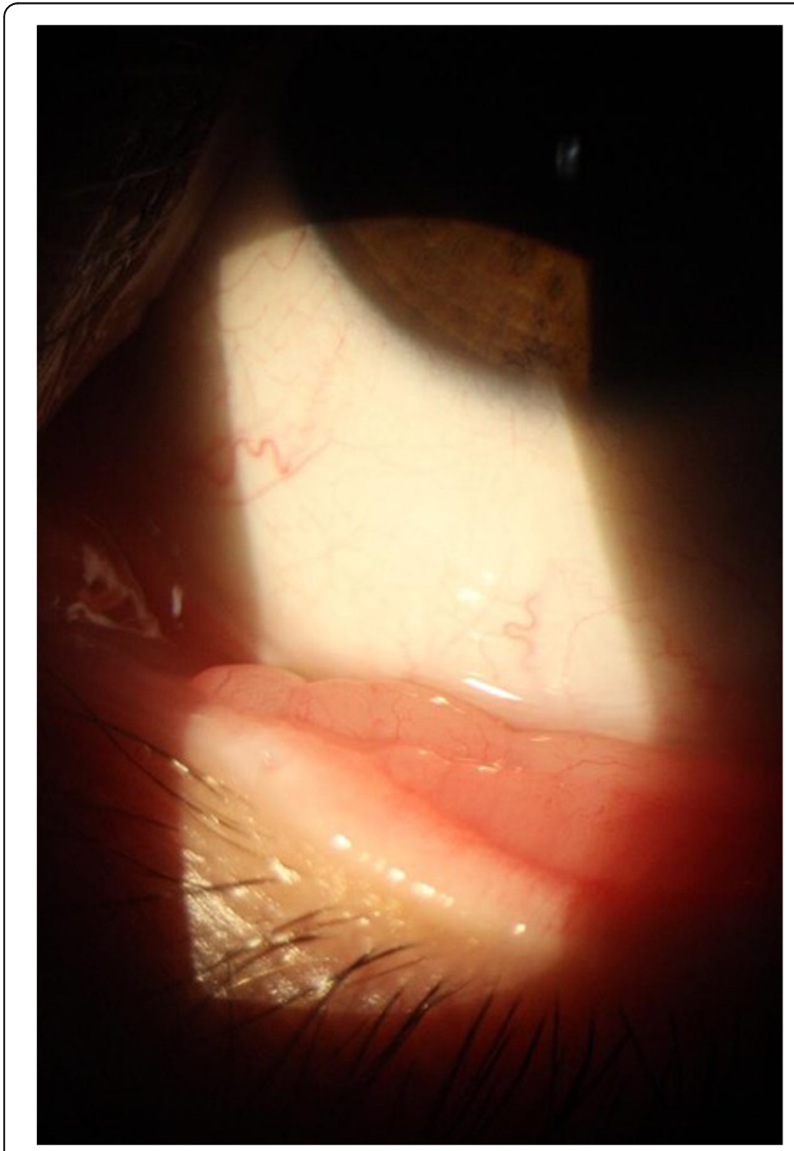

Fig. 4 Oculosporidiosis of tarsal conjunctiva (image courtesy of Prof. Elaine de Paula Fiod Costa, UFMA) though oculosporidiosis is not frequently diagnosed, it should be included as a possible underlying cause of chronic tarsal conjunctival lesions in countries with climate and rural activities. Habit to bath in pounds and stagnant water were associated with the infection. The clinical diagnosis of rhinosporidiosis is not easy (mainly in the ocular form), the histopathological examination is essential to confirm the diagnosis. The eosinophilia observed in the blood count may be a factor that helps in the diagnosis. Treatment of the disease is simple, and its prognosis is good.The research developed aims to provide more clinical and epidemiological information, complementing the scarce existing theoretical reference, so that health professionals may have more knowledge about this disease existing in the region, and its forms of presentation.

\section{Abbreviations}

HU-UFMA: University Hospital of Federal University of Maranhão; $R$. seeberi: Rhinosporidium Seeberi

\section{Acknowledgements}

Not applicable.

\section{Authors' contributions}

FAA, AALTJ, JDP, EFC and GEBS contributed equally in the study design, data collection, estatistical analysis, writing and revision of manuscript. All authors approved the final manuscript.

\section{Funding}

This study received no funding.

\section{Availability of data and materials}

The datasets used and/or analyzed during the current study available from the corresponding author on reasonable request.

\section{Ethics approval and consent to participate}

This research follows the precepts and norms of the Brazilian National Health Council, Resolution 510/16, and is approved by the COMIC-HUUFMA scientific commission with protocol number 87208418.7.0000.5086. The Ethical Committee approved consent waiver request.

\section{Consent for publication}

All authors agreed to publish this article.

\section{Competing interests}

The authors declare that they have no competing interests.

\section{Author details \\ ${ }^{1}$ Laboratory of Immunofluorescence and Electron Microcopy (LIME), Presidente Dutra University Hospital, Federal University of Maranhão, São Luís, Maranhão, Brazil. ${ }^{2}$ Postgraduate Program in Adult Health (PPGSAD), Federal University of Maranhão, São Luís, Maranhão, Brazil. ${ }^{3}$ Department of Medicine I, Federal University of Maranhão, São Luís, Brazil. ${ }^{4}$ Department of Pathology, Ribeirão Preto Medical School, University of São Paulo, Ribeirão Preto, São Paulo, Brazil. ${ }^{5}$ Barão Itapary Street, 227, 65020 070, São Luís, Maranhão, Brazil.}

Received: 13 March 2019 Accepted: 22 October 2019

Published online: 08 November 2019

\section{References}

1. Basu SK, Bain J, Maity K, Chattopadhyay D, Baitalik D, Majumdar BK, Gupta V, Kumar A, Dalal BS, Malik A. Rhinosporidiosis of lacrimal sac: an interesting case of orbital swelling. J Nat SciBiol Med. 2016 Jan-Jun;7(1):98-101. 
2. Sarkar S, Panja S, Bandyopadhyay A, Roy S, Kumar S. Rhinosporidiosis of parotid duct presenting as consecutive bilateral facial swelling: a rare case report and literature review. J ClinDiagn Res. 2016 Mar;10(3):PD14-6.

3. Jacob P, Rose JS, Hoshing A, Chacko G. Tectonic corneal graft for conjunctivalrhinosporidiosis with scleral melt. Indian J Ophthalmol. 2011;59:251-3.

4. Sinha A, Phukan JP, Bandyopadhyay G, Sengupta S, Bose K, Mondal RK, Choudhuri MK. Clinicopathological study of rhinosporidiosis with special reference tocytodiagnosis. J Cytol. 2012;29(4):246-9.

5. Kundu AK, Phuljhele $S$, Jain M, Srivastava RK. Osseous involvement inrhinosporidiosis. Indian J Orthop. 2013;47(5):523-5.

6. Salim T, Komu F. Varied presentations of cutaneous Rhinosporidiosis: report of three cases. Indian J Dermatol. 2016 Mar-Apr;61(2):209-12.

7. Almeida FA, FeitozaLde M, Pinho JD, Mello GC, Lages JS, Silva FF, Silva RR, Silva GE. Rhinosporidiosis: the largest case series in Brazil. Rev Soc Bras Med Trop. 2016:49(4):473-6.

8. Miziara HL, Santos FAM, Kalil RK. Rinosporidiose nasal - aspectos epidemiológicos e anatomo-patológicos em 10 casos. Rev Pat Trop. 1972;1:473.

9. Silva JF, Silva WM, Nogueira AM, Cavalcante SE. Rinosporidiose nasal estudo de 11 casos. Rev Soc Bras Med Trop. 1975;9:19-25.

10. Nuruddin M, Mudhar HS, Osmani M, Roy SR. Lacrimal sac rhinosporidiosis: clinical profile and surgical management by modified dacryocystorhinostomy. Orbit. 2014;33(1):29-32.

11. Prasad V, Shenoy VS, Rao RA, Kamath PM, Rao KS. Rhinosporidiosis: a chronic tropical disease in lateral Pharyngeal Wall. J ClinDiagn Res. 2015;9(5): MD01-2.

12. Pal DK, Mallick AA, Majhi TK, Biswas BK, Chowdhury MK. Rhinosporidiosis in Southwest Bengal. Trop Dr. 2012 Jul;42(3):150-3

13. Kaimbo KW, Parys-Van GR. Conjunctivalrhinosporidiosis: a casereport from a Congolese patient. Bull SocBelgeOphtalmol. 2008;(309-310):19-22.

14. Uledi S, Fauzia A. Human nasal rhinosporidiosis: a case report from Malawi. Pan Afr Med J. 2011;9:27 Epub 2011 Jul 18.

15. Shah $S$, Lavaju $P$, Bharati $P$, Joshi I. A case report of an unusual presentation of ocular rhinosporidiosis as a conjunctival cystic mass. Orbit. 2017;36(1):55-7.

16. John D, Selvin SST, Irodi A, Jacob P. Disseminated Rhinosporidiosis withConjunctival involvement in an Immunocompromised patient. Middle East Afr JOphthalmol. 2017;24(1):51-3.

17. Mukherjee B, Mohan A, Sumathi V, Biswas J. Infestation of the lacrimal sac by Rhinosporidiumseeberi: a clinicopathological case report. Indian J Ophthalmol. 2013;61(10):588-90.

18. Costa EF, Pinto LM, Campos MAG, Gomes TM, Silva GEB. Partial regression oflarge anterior scleral staphyloma secondary to rhinosporidiosis after corneoscleralgraft - a case report. BMC Ophthalmol. 2018;18(1):61.

19. Nair AG, Ali MJ, Kaliki S, Naik MN. Rhinosporidiosis of the tarsal conjunctiva. Indian J Ophthalmol. 2015;63(5):462-3.

20. Sood N, Agarwal MC, Gugnani HC. Ocular rhinosporidiosis: a case report from Delhi. J Infect DevCtries. 2012;6(11):825-7

21. Senaratne T, Edussuriya K, Dhanapala M, Bandara A, Arseculeratne S. Ocular rhinosporidiosis with staphyloma formation: a case with unusual features. Eye Brain. 2011:3:1-4.

22. Senaratne $T$, Senanayake $S$, Edussuriya $K$, Wijenayake $P$, Arseculeratne $S$. Ocular rhinosporidiosis with staphyloma formation: The first report in Sri Lanka. J Infect Dis Antimicrob Agents. 2007;24:133-41.

23. Bhandary S, Natesh V, Chettri S, Kumar A. Rhinosprodiosis: analysis of cases presenting to a tertiary care hospital in Nepal. Internet J Trop Med. 2012:8(1)

24. Gichuhi S, Onyuma T, Macharia E, Kabiru J, Zindamoyen AM, Sagoo MS, Burton MJ. Ocular rhinosporidiosis mimicking conjunctival squamous papilloma in Kenya - a case report. BMC Ophthalmol. 2014;14:45.

25. Banjara H, Panda RK, Daharwal AV, Sudarshan V, Singh D, Gupta A. Bronchial rhinosporidiosis: An unusual presentation. Lung India. 2012;29:173-5.

26. Rogers S, Waring D, Martin P. Recurrent lacrimal sac rhinosporidiosisinvolving the periocular subcutaneous tissues, nasolacrimal duct and nasopharynx. Orbit. 2012;31(5):358-60.

27. Shrestha SP, Hennig A, Parija SC. Prevalence of rhinosporidiosis of the eye and its adnexa in Nepal. Am J Trop Med Hyg. 1998;59(2):231-4.

28. Prabhu SM, Irodi A, Khiangte HL, Rupa V, Naina P. Imaging features of Rhinosporidiosis on contrast CT.Indian J Radiol. Imaging. 2013;23:212-8.

29. Alhaj TF, Nayak VI, Sriprakash K, Perikal TK. An unusual cause of recurrent bloody tears. Indian J Ophthalmol. 2017;65:409-11.

30. Morelli L, Polce M, Piscioli F, Del Nonno F, Covello R, Brenna A, et al. Human nasal rhinosporidiosis: an Italian case report. Diagn Pathol. 2006;1:25.
31. Sivapathasundharam B, Saraswathi TR, Manjunath K, Sriram G. Rhinosporidiosis of parotid duct. Indian J Dent Res. 2009 Jul-Sep;20(3):388-9.

32. Mithal C, Agarwal P, Mithal N. Ocular and adnexal rhinosporidiosis : the clinical profile and treatment outcomes in a tertiary eye care Centre. Nepal J Ophthalmol. 2012 Jan-Jun;4(1):45-8.

33. Mohapatra M, Banushree CS. Two rare cases of rhinosporidiosis of parotid duct: case reports and review of literature. Ann Maxillofac Surg. 2014;4(2):234-6.

34. Arseculeratne SN. Recent advances in rhinosporidiosis and Rhinosporidiumseeberi. Indian J Med Microbiol. 2002;20:119-31.

\section{Publisher's Note}

Springer Nature remains neutral with regard to jurisdictional claims in published maps and institutional affiliations.
Ready to submit your research? Choose BMC and benefit from:

- fast, convenient online submission

- thorough peer review by experienced researchers in your field

- rapid publication on acceptance

- support for research data, including large and complex data types

- gold Open Access which fosters wider collaboration and increased citations

- maximum visibility for your research: over $100 \mathrm{M}$ website views per year

At BMC, research is always in progress.

Learn more biomedcentral.com/submissions 